\title{
Yapılandırmacılık Yaklaşımının İlköğretim Din Kültürüi ve Ahlak Bilgisi Dersinin Amaçlarının Gerçekleşmesine Etkisi*
}

YILDIZ KIZILABDULLAH

DR., ANKARA Ü. İLAHIYAT FAKÜLTESİ

e-posta: ykizilabdullah@gmail.com

\begin{abstract}
Influence of Structuralism in realizing the aims of Religious Culture and Ethics Course. This article measures differences structuralism shows when it is made to do the job in accordance with the traditional approach in education. Survey has been made over two three groups each of which consists of two groups as the control group and test group. While in the test group, the course is performed with activities compatible with structuralist approach, in the control group they are perfomed in line with the traditional approach.As a result of analysis, the differences between them and the independent parameters thought to have an influence on these differences.
\end{abstract}

key words

structuralism, Religious Culture and Ethics Course, traditional approach

\section{A. Giriş \\ 1. Problem Durumu}

Son dönemlerde öğrenme-öğretme sürecinde, öğretmen ve öğrenci rollerinin değişmesi, teknolojik imkânların artması, öğrenme ortamlarının değişmesi, ölçme ve değerlendirme yöntem ve tekniklerin farklılaşması, öğrenmede ürün temelli ölçme ve değerlendirmenin yanı sıra süreç temelli değer-

* Bu makale, "Yapılandırmacık yaklaşımının İlköğretim Din Kültürü ve Ahlak Bilgisi Dersinin Amaçlarının Gerçekleşmesine Etkisi” adlı doktora tezinden üretilmiştir. 
lendirmeye önem verilmesi gibi unsurlar eğitim programlarının temel belirleyicileri olarak düşünülmektedir.

Daha önceleri eğitim sürecinde daha çok öğretmen merkezi bir anlayış hâkim iken bugün öğrencilerin daha aktif olmaları gereken bir anlayış hâkim olmaya başlamıştır. Bu durum eğitimde referans alınan yaklaşımların değişmesini de beraberinde getirmiştir. Önceleri davranışçı yaklaşımlara göre eğitim programları hazırlanırken, artık öğrenciyi merkeze alan yapılandırmacı yaklaşıma göre eğitim programları hazırlanmaya başlamıştır.

Bu değişim süreci incelendiğinde, 1930'lardan önceki dönemin, daha çok felsefi düzeydeki tartışmaların yaşandığı bir dönem olduğunu, 1930'lardan sonraki dönemin ise bilimsel veriler 1şığında önce fizik bilimlerinin daha sonra da davranışsal bilimlerin egemen olduğu görülecektir. ${ }^{1}$ Bu süreçte, 1960'larda davranışçı kuramın etkisi daha çok hissedilirken, bunu takip eden yıllarda davranışçı anlayıştan bilişselci anlayışa doğru bir kayma yaşanmıştır. Bugün ise, her iki anlayışın yerine, yapılandırmacı yaklaşımın eğitim programlarında yer almaya başladığını söylemek mümkündür.

Önceki programlarda benimsenen davranışçı yaklaşımlara göre ${ }^{2}$, öğrenme öğrenenin davranışlarında gözlenebilen kalıcı değişme olarak kabul edilmekte ve öğrenmenin etki-tepkiye dayalı bir davranış değişmesi süreci olduğu savunulmaktadır. Bu süreçte olumsuz davranışlar cezalandırılırken olumlu davranışlar pekiştireçlerle ödüllendirilmektedir. Bu yaklaşımlara göre zihinde neler olup bittiği bilinemez. Öğrenmenin oluşup oluşmadığı dışa vurulan davranışlardan anlaşılır. Davranışçıların temel amacı, birey davranışlarının neler olabileceğini önceden haber verip onları kontrol altına almaya çalışmaktır.

Bu ekolün etkisiyle yapılan araştırmalar sonucu, eğitimde "direk öğretim yöntemi"nin uygulanabilirliği ortaya çıkmıştır. Bu yöntem, beş aşamadan oluşmaktadır: Bunlar; hazırlık, öğretim, denetim, alıştırma ve gözden geçirmedir. Bu yöntem, öğretmenin dersin başında öğrencilerin dikkatlerini top-

1 Değişim süreci için bkz. David H. Jonassen, Jane Howland, Joi Moore, Rosse M. Marra, "What is Meaningful Learning", Learning to Solve Problems With Technology, s.13.; Haris, Karen R.\&Alexander, Patricia A., "Integrated, Constructivist Education: Challenge and Reality", Educational Psychology Review, Vol.10, No.2, 1998, s.115.; Mehmet Arif Özerbaş, "Yapılandırmacı Öğrenme Ortamının Öğrencilerin Akademik Başarılarına ve Kalıcılığına Etkisi” Türk Eğitim Bilimleri Dergisi, Güz 2007, 5(4), s. 609-635.; Güliz Aydin\&Ali Günay Balım, "Yapılandırmacı Yaklaşıma Göre Modellendirilmiş Disiplinler Arası Uygulama: Enerji Konularının Öğretimi”, Ankara Üniversitesi Eğitim Bilimleri Fakültesi Dergisi C.38, S.2., 2005, 145-146.

2 Davranışçı öğrenme kuramları için bkz. Catherine Chen, "A Constructivist Approach to Teaching:A Constructivist Approach to Teaching:Implications in Teaching Computer Networking implications in Teaching Computer Networking", Information Technology, Learning, and Performance Journal, Vol. 21, No. 2, Fall 2003, s.18.; Nuray Senemoğlu, Gelişim Öğrenme ve Öğretim, Ertam Matbaacılık, Ankara 1997, s. 91-347 
laması, belli bir konu hakkındaki bilgi ve becerileri direk olarak öğretmesi, bu bilgilerin kazanılıp kazanılmadığını kontrol etmesi, öğrencilerin bunu içselleştirebilmeleri için onları pratiğe yönlendirmesi ve öğrencileri gözden geçirip değerlendirmesinden oluşur. ${ }^{3}$ Bu yaklaşımların etkisini yitirmesiyle, bilişselci yaklaşımlara doğru bir geçiş yaşanmış ve bu geçiş de bir paradigma değişikliğini beraberinde getirmiştir. Bu geçişin, ne kadar değişiklik getirdiğini ortaya koymak için bilişselci yaklaşımlardan da kısaca bahsetmek yerinde olacaktır.

Bilişsel gelişim, bireyin çevresindeki dünyayı anlama ve öğrenmesini sağlayan, aktif zihinsel faaliyetlerdeki gelişim olarak kabul edilmektedir. ${ }^{4}$ Bilişselciler, vurguyu öğretmenler üzerinden öğrencilere kaydırmış, öğrencilerin edindikleri bilgiyi daha önceki bilgileriyle ilişkilendirerek kendi anlayış a larını kurmalarını sağlamak gerektiğini ifade etmişlerdir. Öğretmenler ise bu sürecin kolaylaştırıcıları olarak tanımlanmıştır. Bilişselciler arasında bazı farklılıklar bulunmasına rağmen, hepsinin birleştiği nokta, çevreden duyu organları vasıtasıyla alınan bilgilerin zihinde bir bilgisayarda verilerin işlenmesi gibi işlendiğidir. Bilişselciler, davranışçıların "uyarıcı-tepki" ve "şartlanma" ile açıkladığı öğrenmeyi, zekânın bir ürünü olarak açıklamakta ve öğrenmede zihindeki şemaların rol oynadığını söylemektedirler. ${ }^{5}$

Yukarıda anlatılan davranışçı ve bilişsel yaklaşımlar, eğitimde istenen hedefleri gerçekleştirememiş ve eğitimcileri yeni arayışlara yönlendirmiştir. $\mathrm{Bu}$ bağlamda eğitimcilerin bugün ulaştığı nokta, beyinle ilgili araştırmaların eğitime aktarılması üzerine yapılandırmacı yaklaşımdır. Bu yaklaşımda, öğrencilerin davranışlarının değiştirilmesinde zihnin geliştirilmesine ağırlık verilmektedir. ${ }^{6}$

Yapılandırmacılık, öğretimde davranış ve becerilerden çok bilişsel gelişim ve derin anlamaya odaklanır. ${ }^{7}$ Ancak yapılandırmacılığı bu geleneksel yaklaşımlardan ayıran nokta, öğrenmenin bireyin kendi çabasıyla ve zihninde yapılandırılmasidır.

Yapılandırmacılığa göre bilgi, bireyden bireye doğrudan aktarılamaz. Bilgi, bireyin kendi çabası sonucunda zihninde oluşur. Bu oluşturma sürecinde, bireyin önceki bilgi deneyim ve çevrenin etkisi vardır. Yeni bir bilginin oluş-

3 Davranışçı yaklaşımların eğitime yansımaları hakkında geniş bilgi için bkz. Saban, Öğrenme Öğretme Süreci Yeni Teori ve Yaklaşımlar, s. 122.

4. Senemoğlu, Gelişim Öğrenme ve Öğretim, s. 39.

5 Fitnat Köseoğlu, Nusret Kavak, "Fen Öğretiminde Yapılandırıcı Yaklaşım", G.Ü. Gazi Eğitim Fakültesi Dergisi, Cilt 21, Sayı 1, Ankara 2001, s. 139-148.

6 Güneş, Yapılandırııı Yaklaşımla Sinıf Yönetimi, s. 7.

7 Fosnot, "Constructivism: A Psychological Theory of Learning", Constructivism: Teory, Perspectives and Practice, s. 10. 
turulması ve anlamlandırılması eski ve yeni bilgiler arasında bağlantılar oluşturmasını gerektirir.Yapılandırmacı öğrenme, öğrencinin bilgiyi pasif olarak almasından ziyade, anlama ve bilgiyi edinme sürecine aktif olarak katılması yaklaşımına dayanır. ${ }^{8}$

Yapılandırmacı yaklaşım, öğrencilere bir takım temel bilgi ve becerilerin kazandırılması gerektiğini önemsemekle birlikte, eğitimde bireylerin daha çok düşünmeyi, anlamayı, kendi öğrenmelerinden sorumlu olmayı ve kendi davranışlarını kontrol etmeyi öğrenmeleri gerektiğini vurgular. ${ }^{9}$ Dolayısıyla yapılandırmacı yaklaşımda sorumluluk öğrenciye aittir ve öğrenci eğitim sürecinde kendi varlığını gösterebilmektedir.

Yapılandırmacı yaklaşımda, birey bilgi ile ne kadar meşgul olursa ve o alanda ne kadar derinleşirse, oluşturulan bilginin bireyi yaşamı boyunca o kadar kalıcı olacağı düşünülmektedir. Bilginin bireye öğretmen tarafından öğretilmesi değil, öğrenen tarafından o bilgiden nasıl bir anlam çıkarıldığı önemlidir. ${ }^{10}$

Görüldüğü üzere, öğrenme-öğretme sürecinde bir takım değişiklikler yaşanmış ve yaşanan bu değişmelere paralel olarak, eğitim programlarının yeniden düzenlenmesi ve programın temel unsurlarının yaşanan değişmelere göre yapılandırılması kaçınılmaz bir olgu olarak karşımıza çıkmışır.

Yapılan araştırmalar, öğrencilerin ezberledikleri olguları birleştirmede ya da karşılaştırmada ve gerçek hayatla ilişkisini kurmada zorluk çektiklerini göstermiştir. ${ }^{11}$ Ayrıca öğretmenin tek bilgi aktarıcısı olduğu geleneksel öğrenme yöntemi artık ihtiyaçlara cevap veremez hale gelmiştir. Dolayısıyla öğrencileri birlikte çalışma, düşüncelerini ve bilgiyi özgürce paylaşma veya entelektüel yeteneklerini geliştirmek için modern araçlar kullanma yönünde teşvik etmede başarısız olmaktadır. Bu sorun için önerilen çözüm yollarından biri de öğrencileri yetenekli bireyler olarak hazırlamaktır. Yani öğrenciler okulda öğrendiklerini yaşam boyunca karşılaşabilecekleri farklı ve beklenmeyen durumlarda kullanabilmelidirler. Öğretmenin tek bilgi aktarıcısı, ders kitabının da tek kılavuz olduğu sınıf modeli ile üretici düşünen birey yetiştirilemeyeceği açıktır.

Eğitim programlarının birey ve toplumun geleceğini düzenlemedeki fonksiyonu düşünüldüğünde, birey ve toplum için sağlıklı bir gelecek oluştur-

8 Yapılandırmacılık ile ilgili geniş bilgi için Bkz. Audrey Gray, Contructivist Teaching and Learning, SSTA Research Centre Report, 1997.

9 Bu konuda geniş bilgi için bkz. Saban, Öğrenme Öğretme Süreci Yeni Teori ve Yaklaşımlar, s. 123.

10 Geniş bilgi için bkz. Bünyamin Yurdakul, "Yapılandırmacılık", Eğitimde Yeni Yönelimler, Özcan Demirel (Ed), PegemA Yayıncilık, Ankara 2005, s.41.

11 Erdoğan Tezci, Aysun Gürol, "Oluşturmacı Öğretim Tasarımı ve Yaratıcılık", The Turkish Online Journal of Educational Technology - TOJET, Volume 2, Issue 1, Article 8, January 2003, s.2. 
mak, bilgiye ulaşma, bilgiyi kullanma ve üretme becerilerine bağlı bulunmaktadır. Bu becerilerin kazanılması ve hayat boyu sürdürülmesi bilgi üretimine dayalı çağdaş bir eğitimi zorunlu kılmaktadır.

Milli Eğitim sisteminde bu beklentilere cevap verebilecek eğitim programlarının hazırlanması gerektiği düşünülmektedir. Yapılandırmacılık yaklaşımının, eğitimdeki bu beklentilere cevap verebileceği ve eğitimde geleneksel yaklaşımların çok ötesinde bir eğitim anlayışı getirerek öğrenme-öğretme sürecini yeniden düzenlediği kabul edilmektedir.

Bu bağlamda araştırmada ele alınan temel problem aşağıda şudur: "Yapılandırmacılık Yaklaşımının, İlköğretim Din Kültürü ve Ahlak Bilgisi Dersi'nin Amaçlarının Gerçekleşme Düzeyine Etkisi var mıdır? Geleneksel yaklaşımlara göre bu farklılık ne orandadır ve amaçların gerçekleşme düzeylerine etki etmesi muhtemel faktörler nelerdir?

\section{Denenceler}

1. Araştırmaya katılan öğrencilerin, öntest puanları, deney ve kontrol gruplarına göre anlamlı bir farklılık göstermektedir.

2. İlköğretim Din Kültürü ve Ahlak Bilgisi Dersinde belirlenen ünitelerde yapılandırmacılık yaklaşımına uygun olarak hazırlanan etkinliklerle desteklenerek gerçekleştirilen öğretimin uygulandığı grup (deney grubu) ile geleneksel yaklaşımlara göre öğretimin uygulandığı grup (kontrol grubu), öğrenme düzeyleri açısından (sontest puanları bakımından) bir farklılık göstermektedir.

3. Deney ve kontrol gruplarının dersteki kalıcılık testi sonuçları arasında anlamlı bir farklılık vardır.

4. Araştırmaya katılan kontrol grubundaki öğrencilerin sontest puanları, cinsiyetlerine, öğrencilerin şimdiye kadar yaşadığı yer durumuna, ailenin ekonomik durumuna, annenin öğrenim durumuna, babanın öğrenim durumuna, annenin mesleğine, babanın mesleğine ve çalışma ortamlarına göre farklılaşmaktadır.

5. Deney grubundaki öğrencilerin sontest ortalama puanları, aynı bağımsız değişkenlere göre farklılaşmaktadır.

6. Kontrol grubundaki öğrencilerin kalıcılık puanları, bağımsız değişkenlere göre farklılaşmaktadır.

7. Deney grubundaki öğrencilerin kalıcılık puanları, bağımsız değişkenlere göre farklılaşmaktadır.

\section{Araştırmanın Yöntemi}

Araştırmada Yapılandırmacılık yaklaşımının İlköğretim Din Kültürü ve Ahlak Bilgisi derslerinde kullanımının dersin amaçlarının gerçekleşmesine etki 
edip etmediği araştırılmıştır. Bu amaçla, yapılandırmacılık yaklaşımı ile ilgili literatür taraması da yapılmıştır. ${ }^{12}$ İlgili literatür ışı̆̆ında İlköğretim Din Kültürü ve Ahlak Bilgisi Derslerinde 6.sınıf "Paylaşalım Yardımlaşalım: Zekât ve Sadaka", 7 Sınıf "Kötü Alışkanlıklardan Kaçınalım" ve 8. sınıf "Din Akıl ve Bilim" ünitelerine yönelik bir başarı testi hazırlanmıştır. Bu başarı testi Yapılandırmacılık Yaklaşımının İlköğretim Din Kültürü ve Ahlak Bilgisi Derslerinin amaçlarının gerçekleşmesine etki edip etmediğinin belirlenmesi amacıyla hazırlanarak uygulanmış ve elde edilen ortalama puanların, belirlenen faktörlere göre farklılaşıp farklılaşmadığı araştırılmıştır.

Araştırmada öntest-sontest kontrol gruplu deneysel desen kullanılmıştır. Araştırma iki grup üzerinde gerçekleştirilmiştir. Gruplar tesadüfî yöntem yoluyla deney ve kontrol grubu olarak atanmıştır. Araştırmada belirlenen üniteler, kontrol grubunda geleneksel yöntem ile deney grubunda ise, yap1landırmacılık yaklaşımına uygun olarak hazırlanmış etkinlikler yoluyla işlenmiştir.

\section{4. Çalışma Evreni ve Örneklem}

Araştırmada deneysel desen kullanıldığından evren ve örneklem tayinine gidilmemiştir.

Araştırma Ankara ili Yenimahalle ilçesi Batıkent Müjgan Karaçalı İlköğretim okulundaki 6,7 ve 8 . sınıf öğrencileri üzerinde yapılmıştır. Bu okulunun seçilmesinde, orta sosyo-ekonomik düzeyi temsil ettiği düşünülen öğrencilerden oluşan bir okul olması etkili olmuştur. Bu durum tespiti, okul yöneticileri, semt sakinleri, öğretmenler ve velilerle görüşmeler sonucunda yapılmıştır. Adı geçen okulun 6, 7 ve 8. sınıflarından 148 öğrenci bu araştırmanın uygulama grubunu oluşturmuştur. Seçilen bu 148 öğrenci 6, 7 ve 8 . sinıfların tamamı değil, bu sinıflardan seçilen ve kontrol ve deney grubunu oluşturan kişi sayısıdır. Bu gruplar, sınıfların daha önceki yıllarda almış oldukları akademik notlara bakılarak tesadüfî olarak oluşturulmuştur.

\section{Veri Toplama ve Analiz Teknikleri}

Araştırmada veri toplama aracı araştırmacı tarafından uzman görüşlerine başvurularak hazırlanmış başarı testidir. İlköğretim Din Kültürü ve Ahlak Bilgisi Dersinin amaçları, kazanımları, değerleri, becerileri ve kavramları çerçevesinde 2006-2007 eğitim-öğretim yılı ilköğretim 6, 7 ve 8. sınıfların

12 Literatür taraması, araştırma problemi ile ilgili bilginin literatürün özeti, sentezi ve incelenmesidir. Literatür şu kaynakları içerir: mesleki dergiler, raporlar, bilimsel kitap ve monografiler, hükümet dokümanları ve tezlerdir. Literatür ile ilgili geniş bilgi için bkz. Balcı, Sosyal Bilimlerde Araştırma, s. 63-75. 
müfredatlarına uygun olarak amaçların gerçekleşip gerçekleşmediğini ölçmek amacıyla bir başarı testi oluşturulmuştur. Bu başarı testi, her sınıf için 22'şer sorudan oluşan çoktan seçmeli bir ölçme aracıdır.

Başarı testleri hazırlanırken, İlköğretim Din Kültürü ve Ahlak Bilgisi Dersi öğretim programına göre hazırlanan Milli Eğitim Bakanlığı Talim Terbiye Kurulunca onanan ders kitaplarının muhtevalarından hareket edilmiştir. Sorular oluşturulurken her düzey için amaçlar belirlenmiş, öğrencilerin yaş ve öğrenme seviyeleri dikkate alınmıştır. Oluşturulan sorular 6. sınıftan toplam 39 öğrenci, 7. sinıftan 53 öğrenci ve 8. sinıftan 54 öğrenci olmak üzere toplam 148 öğrenci üzerinde uygulanmıştır.

Belirlenen konulara ilişkin hazırlanan 22 soruluk başarı testine, öğrencilerin verdikleri yanıtlardan elde ettikleri ortalama puanlarla, öğrencilerin o üniteye ait başarıları ölçülmüştür. Başarı testinde elde edilen puanların ortalamaları analiz ve yorumlarda kullanılmıştır.

Analiz sonucu elde edilen puanların bağımsız değişkenlere ${ }^{13}$ göre farklılaşmalarını belirlemek için bağımsız değişkenin niteliğine göre "iliş̧kisiz örneklemler t-testi" ve "ilişkili örneklemler t-testi" yapılmıştır. Bağımsız değişkenlerden ikiden fazla alt kategorisi olan değişkenlere göre farklılaşmalarını belirlemek amacıyla da "Anova testi” yapılmıştır. Analizler neticesinde farklılaşma olduğu sonucuna ulaşılmışsa, bu farkın kaynağını bulmak için, "LSD post-hoc çoklu karşılaştırma testi" kullanılmıştır. Değişkenler arasında ilişkiyi görmek için ise korelasyon testlerine başvurulmuştur.

Yapılandırmacılık yaklaşımı, eğitim-öğretim sürecinde, ürünün yanında sürece de büyük önem atfetmektedir. Aslı itibariyle süreç, üründen daha önemli görülmekle birlikte, eğitim-öğretimin belli bir alanda yapılıyor olması ürünü de hesaba katmayı gerektirmektedir. Bu bağlamda, araştırmanın yapıldığı dersin muhtevası gereği ve seçilen ünitelerin kazanımları gereği yapılan araştırma ünitelerin amaçlarının gerçekleşme düzeylerini belirlemeye yönelik olarak gerçekleştirilmiştir. ${ }^{14}$ Araştırmada, belirlenen kontrol ve deney grubu arasındaki farklılaşma düzeylerini belirlemek amacıyla her iki gruba aynı ölçme aracının uygulanması gerekmektedir. Dolayısıyla bu ölçme aracı, bir başarı testi olarak belirlendiğinde her ne kadar deney grubu etkinlik merkezli yürütülse de aynı muhtevanın aynı ölçme aracıyla ölçül-

13 Bu konuda etkisi olabileceği düşünülen bağımsız değişkenler ise cinsiyet, ailelerinin ekonomik durumu, öğrenci annelerinin eğitim seviyesi, babalarının eğitim seviyesi, annelerinin meslekleri, babalarının meslekleri, öğrencilerin şimdiye kadar ikamet ettikleri yerler, okul dışında eğitim alıp almamaları, sahip oldukları kardeş sayısı ve çalışma ortamlarıdır.

14 Araştırmada seçilen ünitelerin amaçları, kazanımları ve süreç içerisinde gerçekleştirilen etkinlikler ekte sunulmuştur. 
müş olması her iki grubun eşit ölçülmesini sağlamıştır. Aksi takdirde doğru bir ölçüm olamayacak, nesnel bir karşılaştırma yapılamayacaktır.

Yapılandırmacılık yaklaşımında, öğrencilerin eğitim-öğretim sürecinin büyük önemi olmasının yanında öğretim olgusunun belli bir alanda belli konular çerçevesinde yapılıyor olması bu durumu bir ölçüde kısıtlamaktadır. Yaklaşım öğrencilerin kazanımlarını kendilerinin edinmeleri gerektiğini, belli hedefler koymanın bunu sınırlandıracağını belirtmektedir. Daha önceki programlar da, özellikle bu açılardan eleştirilmekte ve yapılandırmacılık yaklaşımı ile bu durumun aşılabileceği iddia edilmektedir. Ancak program incelendiğinde her ne kadar amaç cümleleri yok ise de bunun yerine kazanım ifadeleri konmakta ve öğrencilerin yine bunlara ulaşmaları beklenmektedir. Dolayısıyla program yapılandırmacılık yaklaşımını bu bağlamda sınırlamaktadır. Başarı testi yanında daha süreç merkezli bir değerlendirmenin seçilmemiş olması bu sınırlamadan dolayı meydana gelmiştir.

Ayrıca ders açısından bir tutum ölçeği yapılması düşünülmüş, bu durum yine dersin doğasından kaynaklanan bazı çekincelerden dolayı gerçekleştirilememiştir.

\section{Veri Toplama Aracının Geçerlik ve Güvenirliği}

Yapılan çalışmalarda çalışmanın türüne göre farklı geçerlik ve güvenirlik hesaplamaları yapılmaktadır. ${ }^{15} \mathrm{Bu}$ araştırmada kullanılan başarı testinin geçerlik ve güvenirliğini test emek amacıyla iteman madde analizi programı uygulanmıştır. Madde analizi Ankara İli Yenimahalle ilçesi Batıkent Müjgan Karaçalı İlköğretim Okulunda tesadüfî örneklem yolu ile seçilen 6. sınıftan 40, 7. Sinıftan 55, 8. sınıftan 55 olmak üzere üç sınıftaki toplam 150 öğrencinin öntest puanlarından elde edilen veriler üzerinde gerçekleştirilmiştir. Analiz sonucu başarı testinin alfa güvenilirlik katsayısı 6. sınıflar için 0.73 , 7. sınıflar için 0.71 ve 8 . sınıflar için 0.70 olarak tespit edilmiştir. Tespit edilen bu rakamlar uygulanan ölçme aracının geçerli ve güvenilir olduğunu göstermektedir.

\section{Uygulamanın Gerçekleştirilmesi}

Araştırmada, İlköğretim Din Kültürü ve Ahlak Bilgisi Dersi 6.sınıf "Paylaşalım Yardımlaşalım: Zekât ve Sadaka", 7. Sınıf "Kötü Alışkanlıklardan Kaçınalım" ve 8. sınıf "Din Akıl ve Bilim" ünitelerinin konularına ve bu konuların kazanımlarının gerçekleşmesine yönelik ve yapılandırmacı yaklaşım ışı-

15 Geçerlik güvenirlik hesaplamalarında geniş bilgi için bkz. Tavşancıl, Tutumların Ölçülmesi ve SPSS ile Veri Analizi. 
ğında etkinlikler hazırlanmıştır. Bu yaklaşıma yönelik ders işlenmesinin İlköğretim Din Kültürü ve Ahlak Bilgisi Dersinin amaçlarının gerçekleşmesine etkisi olup olmadığını araştırmak üzere Ankara ili Yenimahalle ilçesi Batıkent Müjgan Karaçalı İlköğretim Okulunda tesadüfî olarak seçilen her sınıftan iki grup öğrenciyle uygulama gerçekleştirilmiştir. Uygulamanın yapıldığı okulda seçilen sınıflardan biri deney grubu, diğeri ise kontrol grubu olarak belirlenmiştir. Bu gruplar oluşturulurken öğrencilerin daha önceki başarı durumları göz önünde bulundurulmuştur. Araştırmanın gerçekleştirildiği okula gidilip uygulamanın gerçekleştirileceği sınıflar belirlendiğinde, uygulamaya geçmeden önce araştırmacı önce kendisini tanıtmış daha sonra ise öğrencilerde bir güven ortamı oluşturmak için nasıl bir araştırma yapıldığını, bu araştırmanın hangi süreçlerden oluştuğunu öğrencilerle paylaşmış ve öğrencileri araştırma için güdüleyerek hazır hale getirmiştir.

Bu süreçte adı geçen okulda bulunan 6/C, 7/C ve 8/A sinıfları deney, 6/ A, 7/A ve 8/C sınıfları ise kontrol grubu olarak belirlenmiştir. Bu belirleme tesadüfî olarak yapılmıştır.

Deney grubu olarak belirlenen 6/C, 7/C ve 8/A siniflarında ders, yap1landırmacı yaklaşım ışığında hazırlanan etkinliklerle işlenmiştir. Dersler yapılandırmacılık yaklaşımında bulunan ve $5 \mathrm{E}$ modeli olarak bilinen model göz önünde bulundurularak işlenmiştir. ${ }^{16}$

Kontrol grubu olarak belirlenen 6/A, 7/A ve 8/C sınıflarında ise geleneksel yöntemlerle ders işlenmiştir. Bu gruplarda dersler, düz anlatım ve soru cevap yöntemi doğrultusunda sürdürülmüştür.

Deney ve kontrol gruplarına her ünitenin başlangıcında öntest dediğimiz 6. Sinıflar için 22, 7. sinıflar için 22 ve 8. sinıflar için 22 sorudan oluşan başarı testi uygulanmıştır. Deney grubunda dersler yapılandırmacılık yaklaşımına uygun etkinlikler çerçevesinde araştırmacı tarafından işlenirken, kontrol grubunda ise dersin öğretmeni tarafından işlenmiştir. Ünite sonunda her iki grubun konu bitiminde edindikleri düzeyi belirlemek ve önce yapılan test ile farkını ortaya koyabilmek amacıyla sontest uygulanmıştır. Öntestte uygulanan testin aynısı sontest olarak uygulanmıştır. Konu bitiminden 1,5 ay sonra öğrenilen bilgilerin kalıcılı̆̆ının ne olduğunu belirlemek amacıyla da kalıcılık testi uygulanmıştır. Öntest ve sontestte uygulanan başarı testi, kalıcılık testi olarak uygulanmıştır.

16 Bu model, beş aşamadan oluşmakta ve her aşama İngilizcede E harfi ile başladığından bu isimle adlandırılmaktadır. İlk aşama giriș (enter), ikinci aşama keşfetme (explore), üçüncü aşama açılama (explain), dördüncü aşama derinleşme (elaborate), beşinci aşama değerlendirme (evaluate) aşamalarından oluşmaktadır. 


\section{Temel Kavramlar}

\section{1. Illköğretim}

6-14 yaşlarındaki çocukların eğitim ve öğretimini kapsayan; kız ve erkek bütün vatandaşlar için zorunlu ve devlet okullarında parasız olan eğitim kademesidir. ${ }^{17} 18$ Ağustos 1997 yılında çıkarılan 4306 sayılı yasa ile tüm yurtta 8 yıllık zorunlu ilköğretim uygulamasına geçilmiştir. Böylece hem daha nitelikli bireylerin yetiştirilmesi yönünde önemli adımlar atılmış hem de programlarda bütünlük sağlama yoluna gidilmiştir. İlköğretim süresinin 8 yıla çıkarılmasıyla ilkokul ve ortaokulların programlarının birleştirilmesi sağlanmıștır.

İlköğretimin amac1; "Her Türk çocuğuna iyi bir vatandaş olmak için gerekli temel bilgi, beceri, davranış ve alışkanlıkları kazandırmak, onu millî ahlâk anlayışına uygun olarak yetiştirmek ve her Türk çocuğunu ilgi, İstidat ve kabiliyetleri yönünde yetiştirerek hayata ve üst öğrenime hazırlamaktır." ${ }^{18} \mathrm{Bu}$ anlamda ilköğretim birey için gelecekteki öğrenim kademelerinin temelini oluşturmakta ve ona gerekli bilgi ve becerileri kazandırmaktadır.

Yapılan bu çalışma, ilköğretim dönemi öğrencilerini temel alarak, ilköğretim genel amaçlarını göz önünde bulundurmuştur.

\section{2. İlköğretim Din Kültürü ve Ahlak Bilgisi Dersi}

İlköğretim Din Kültürü ve Ahlak Bilgisi Dersi, "illköğretim ve Ortaöğretimde öğrenciye, Türk Milli Eğitiminin genel amaçlarına, ilkelerine ve Atatürk'ün laiklik ilkesine uygun, din, İslam Dini ve ahlak bilgisi ile ilgili yeterli temel bilgi kazandırmak, Atatürkçülüğün, milli birlik ve beraberliğin, insan sevgisinin dini ve ahlaki yönden pekiştirilmesini sağlamak, iyi ahlaklı ve faziletli insanlar yetiştirmek" amacıyla Anayasanın 24. maddesinde devletin gözetim ve denetimi altında ilk ve ortaöğretim kurumlarında zorunlu olduğu belirtilen bir derstir.

\subsection{Amaç}

Amaç; "Bir öğrencinin planlanmış ve tertiplenmiş yaşantılar sayesinde kazanması kararlaştırılan ve davranış değişikliği ya da davranış olarak ifade edilmeye elverişli olan özelliklerdir."19

17 MEB. Tebliğler Dergisi, c. 60, sayı:2481, Ekim 1997.

18 Milli Eğitim Temel Kanunu İle İlköğretim ve Eğitim Kanunu, MEB. Basımevi, Ankara, 1990, s. 13

19 İlköğretim Din Kültürü ve Ahlak Bilgisi (4, 5, 6, 7, 8. Sinıflar için) Öğretim Programı ve Kılavuzu, s. 31 
Kazanımlar, öğrenme süreci içerisinde planlanmış ve düzenlenmiş yaşantılar sayesinde, öğrencilerin kazanması kararlaştırılan bilgi, değer, beceri ve tutumlardır. ${ }^{20}$

\subsection{Değer}

Değer, "Bir sosyal grup veya toplumun kendi varlık, birlik, işleyiş ve devamını sağlamak ve sürdürmek için üyelerinin çoğunluğu tarafından doğru ve gerekli oldukları kabul edilen ortak düşünce, amaç, temel ahlaki ilke ya da inançlardır." ${ }^{21}$ Değerler, yapılandırmacılık yaklaşımında üzerinde önemle durulan hususlardan biri olduğu için çalışmamızda yer alacaktır.

\subsection{Beceri}

Beceri; "Öğrencilerde, öğrenme süreci içerisinde kazanılması, geliştirilmesi ve yaşama aktarılması tasarlanan kabiliyetlerdir." 22 Yapılandırmacılık yaklaşımının temelinde öğrencilerin birtakım beceriler edinmelerini sağlamak yer aldığından beceriler de bu çalışmada yer alacak konulardan biridir.

\subsection{Yapılandırmacılık Yaklaşımı}

Yapılandırmacılık, temelde öğrencilerin mevcut bilgilerini kullanarak yeni bilgi edinmelerini, öğrenmeyi ve kendine özgü bilgi oluşturmayı açıklamaya çalışan bir öğrenme kuramıdır. ${ }^{23}$

Yapılandırmacılık, öğretimle ilgili bir kuram değil, bilgi ve öğrenme ile ilgili bir kuramdır. Bu kuram bilgiyi temelden kurmaya dayanır. Özünde, öğrenin bilgiyi yapılandırması ve uygulamaya koyması vardır. ${ }^{24}$

\subsection{Geleneksel Öğretim Yöntemi}

Geleneksel öğretim yöntemi, bilginin öğretenden öğrenene doğru gerçekleştiği, öğrencinin aktif katılımının olmadığı, öğretmenin sorular sorduğu, konuyu öğrencilere okuttuğu, gerektiğinde konuyu anlattırdığı ve anlattığı, ödevleri kontrol ettiği, ödevlere yönelik olarak öğrencilere artı eksi verdiği, yeni konuyla ilgili öğrencilere ödevler verdiği bir öğretim yöntemidir

20 İlköğretim Din Kültürü ve Ahlak Bilgisi (4, 5, 6, 7, 8. Sinıflar için) Öğretim Programı ve Kılavuzu, s. 31

21 İlköğretim Din Kültürü ve Ahlak Bilgisi (4, 5, 6, 7, 8. Sinıflar için) Öğretim Programı ve Kılavuzu, s. 31

22 İlkögrretim Din Kültürü ve Ahlak Bilgisi (4, 5, 6, 7, 8. Sinıflar için) Öğretim Programı ve Kılavuzu, s. 31

23 Haluk Özmen, "Fen Öğretiminde Öğrenme Teorileri ve Teknoloji Destekli Yapılandırmacı (Constructivist) Öğrenme", The Turkish Online Journal of Educational Technology - TOJET, Volume 3, Issue 1, Article 14, January 2004.

24 Hasan H. Şaşan, "Yapılandırmacı Öğrenme", Yaşadıkça Eğitim, S. 74-75, 2002. s. 49-52. 


\section{B. Kontrol ve Deney Grubu Öğrencilerinin Öntest Sontest ve Kalıcılık Puanlarının Karşılaştırılması}

Bu bölümde araştırmaya katılan 6, 7 ve 8. sınıf öğrencilerinin almış oldukları öntest, sontest ve kalıcılık puanlarına ait bulgular tablolar halinde verilmiş ve yorumları yapılmıştır.

Tablo 1: 6., 7. ve 8. Sinıf Deney ve Kontrol Grubu Öntest Puanlarının Karşılaştırılması

\begin{tabular}{|c|c|c|c|c|c|c|c|}
\hline \multicolumn{2}{|c|}{ Öntest } & $\mathrm{N}$ & $X$ & S & sd & $\mathrm{t}$ & $\mathrm{p}$ \\
\hline \multirow{2}{*}{ 6. Sinif } & Kontrol & 21 & 13.76 & 3.46 & 37 & -.656 & .516 \\
\hline & Deney & 18 & 14.44 & 2.95 & & & \\
\hline \multirow{2}{*}{ 7. Sinif } & Kontrol & 27 & 16.29 & 3.13 & 51 & .124 & .902 \\
\hline & Deney & 26 & 16.19 & 2.95 & & & \\
\hline \multirow{2}{*}{ 8. Sinıf } & Kontrol & 24 & 15.50 & 3.14 & 52 & 1.706 & .094 \\
\hline & Deney & 30 & 14.00 & 3.25 & & & \\
\hline
\end{tabular}

Tablo 1 incelendiğinde, araştırmaya katılan 6. (t(37)=-.656, $\mathrm{p}>.05), 7$. $(\mathrm{t}(51)=.124, \mathrm{p}>.05)$ ve $8 .(\mathrm{t}(52)=.094, \mathrm{p}>.05)$ Sinif kontrol grubundaki öğrencilerin, öntest ortalama puanlarının, deney grubu öntest ortalama puanlarına göre anlamlı bir farklılık göstermediği görülecektir.

Grupların almış olduğu puanlar oldukça birbirine yakındır. Buna göre gruplar arasında istatistiksel bir fark bulunmamaktadır. Yapılan öntestlerin ilk amacı öğrencilerin ön öğrenmeleri hakkında bir fikir edinmek iken, ikinci amacı araştırmanın gerçekleştirildiği grupların ön öğrenmeler açısından birbirine denk olup olmadığını ortaya koymak ve denk grupları seçerek araştırmayı bu gruplar üzerinde gerçekleştirmeye yardımcı olmaktır.

Araştırmanın başlangıcında bu gruplar tesadüfü olarak seçilmiş olmasına rağmen uygulanan öntest neticesinde her iki grubun birbirine denk olduğu anlaşılınca uygulamaya bu sınıflarda devam edilmesi uygun görülmüştür.

Tablo 2 incelendiğinde, 6 . $(\mathrm{t}(37)=.601, \mathrm{p}>.05)$., 7. $(\mathrm{t}(51)=-1.374$, $\mathrm{p}>.05)$.ve 8 . $(\mathrm{t}(52)=-.670, \mathrm{p}>.05)$. Sinif deney grubunun sontest puanı ile 
Tablo 2: 6., 7. ve 8. Sinıf Deney ve Kontrol Grubu Sontest Puanlarının Karşılaştırılması

\begin{tabular}{|c|c|c|c|c|c|c|c|}
\hline \multicolumn{2}{|c|}{ Sontest } & N & $\bar{X}$ & S & sd & t & p \\
\hline \multirow{3}{*}{ 6. Sinıf } & Kontrol & 21 & 17.42 & 2.71 & 37 & .601 & .551 \\
& Deney & 18 & 16.88 & 2.88 & & & \\
\hline \multirow{3}{*}{ 7. Sinıf } & Kontrol & 27 & 16.70 & 3.29 & 51 & -1.374 & .175 \\
& Deney & 26 & 17.84 & 2.72 & & & \\
\hline \multirow{2}{*}{ 8. Sinıf } & Kontrol & 24 & 16.66 & 2.63 & 52 & -.670 & .506 \\
& Deney & 30 & 17.13 & 2.47 & & & \\
\hline
\end{tabular}

kontrol grubunun sontest puanı arasında istatistiksel olarak anlamlı bir farklılaşma bulunmadığg görülmektedir.

Bu bulgu, geleneksel yöntemlerle ders işlenen kontrol grubunun sontest puanının yapılandırmacı yaklaşıma yönelik etkinlikler çerçevesinde ders işlenen deney grubunun sontest puanına göre istatistiksel anlamda bir farkl1lık taşımadığını göstermektedir. İki grup arasında matematiksel anlamda bir fark bulunmasına rağmen, bu fark istatistiksel anlamda bir fark teşkil etmemektedir.

Farklı bir yöntemin denendiği deney grubunda, kontrol grubuna göre bir fark çıkmamasının nedeni, öğrencilerin alışmış oldukları yöntemin geleneksel yöntem olması ve öğrencilerin çalışmalarını bu yönde gerçekleştirmelerinde aranabilir.

Tablo 3 incelendiğinde, $6 .(\mathrm{t}(37)=-1.290, \mathrm{p}>.05)$. ve 7. $(\mathrm{t}(51)=.680$, $\mathrm{p}>.05$ ). Sinıf deney grubunun kalıcılık puanı ile kontrol grubunun kalıcılık puanı arasında istatistiksel olarak anlamlı bir farklılaşma bulunmadığı görülmektedir.

Her iki sınıfın grupları arasında kalıcılık testi ortalama puanları arasında istatistiksel anlamda bir farklılık bulunmamasına rağmen, son testleri ile karşılaştıracak olursak, yapılandırmacılık yaklaşımına uygun olarak düzenlenen etkinlikler çerçevesinde ders işlenen deney grubunun kalıcılık testi ortalama puanı diğer gruba göre öğrencilerin lehine olacak şekilde artmıştır 
Tablo 3: 6., 7. ve 8. Sinıf Deney ve Kontrol Grubu Kalıcılık Puanlarının Karşılaştırılması

\begin{tabular}{|c|c|c|c|c|c|c|c|}
\hline \multicolumn{2}{|c|}{ Kalıcılık } & $\mathrm{N}$ & $\overline{\mathrm{X}}$ & S & sd & $\mathrm{t}$ & $\mathrm{p}$ \\
\hline 6. Sinıf & $\begin{array}{l}\text { Kontrol } \\
\text { Deney }\end{array}$ & $\begin{array}{l}21 \\
18\end{array}$ & $\begin{array}{l}16.47 \\
17.50\end{array}$ & $\begin{array}{l}2.50 \\
2.43\end{array}$ & 37 & -1.290 & .205 \\
\hline 7. Sinıf & $\begin{array}{l}\text { Kontrol } \\
\text { Deney }\end{array}$ & $\begin{array}{l}27 \\
26\end{array}$ & $\begin{array}{l}18.14 \\
17.73\end{array}$ & $\begin{array}{l}1.99 \\
2.45\end{array}$ & 51 & .680 & .500 \\
\hline 8. Sinıf & $\begin{array}{l}\text { Kontrol } \\
\text { Deney }\end{array}$ & $\begin{array}{l}24 \\
30\end{array}$ & $\begin{array}{l}19.95 \\
17.50\end{array}$ & $\begin{array}{l}1.12 \\
2.73\end{array}$ & 40.215 & 4.470 & .000 \\
\hline
\end{tabular}

denebilir. Deney grubundaki kalıcılık testi ortalama puanı aynı grubun son testine göre artış gösterirken, kontrol grubunda bu durum tam tersi olacak şekilde gözlenmiştir.

Ancak 8. sınıf açısından, araştırmaya katılan kontrol ve deney grubundaki öğrencilerin kalıcılık testi puanları arasında kontrol grubunun lehine anlamlı bir farklilık mevcuttur. (t(40.215) $=4.470, \mathrm{p}<.05)$.

C. Kontrol ve Deney Grubu Öğrencilerinin Sontest ve Kalıcılık

Puanlarının Bağımsız Değişkenlere Göre karşılaştırılması

Araştırmanın son dört denencesi, kontrol ve deney grubunun sontest ve kalıcılık puanlarının belirlenen bağımsız değişkenlere göre farklılaşmalarını ortaya koymaya yönelik olarak belirlenmiştir. Bu bağımsız değişkenler, cinsiyet, öğrencilerin şimdiye kadar yaşadığı yer, ailenin ekonomik durumu, annenin öğrenim durumu, babanin öğrenim durumu, annenin mesleği, babanin mesleği ve çalışma ortamlarıdır.

$\mathrm{Bu}$ çalışmanın sınırlılıkları çerçevesinde, sontest ve kalıcılık puanlarına etki etme bakımından anlamlı farklılıklar gösteren bağımsız değişkenlere değinilmiştir. ${ }^{25}$ 
Bu durum 6. Sinıf kontrol grubunda, sontest puanları, baba eğitimine göre (.037); kalıcılık puanları, gelir durumuna göre (.004) ve kardeş sayısına göre (.00) anlamlı bir şekilde farklılaşmaktadır. 6. Sınıf deney grubunda ise, kalıcılık puanları, deneklerin çalışma ortamlarına (.04) ve baba eğitimine (.04) göre anlamlı bir farklılık göstermektedir.

7. Sınıf kontrol grubunda, sontest puanlarının anne eğitimine göre (.013), kalıcılık puanları çalışma ortamlarına göre (.00) anlamlı bir farklılık göstermektedir.

8. sınıf kontrol grubunda sontest puanları cinsiyete göre (.01), çalışma ortamlarına göre (.01) ve baba eğitimine göre (.046), kontrol grubu kalıc1lık puanları baba mesleğine göre (.003); deney grubu sontest puanları, deneklerin eğitim desteği alıp almamalarına göre (.00), kalıcılık puanlarının eğitim desteği alıp almamalarına göre (.02) anlamlı bir şekilde farklılaşmaktadır.

\section{SONUÇ}

Araştırmamızın sonuçlarına göre, amaçların gerçekleşme düzeyi oldukça yüksek çıkmış olmasına rağmen, kontrol ve deney grupları arasında ciddi anlamda bir farklılık gözlenmemiştir. Ancak bu durum sonuç olarak değerlendirildiği takdirde böyledir. Yapılandırmacı yaklaşımın süreç değerlendirmeyi de içerdiği düşünüldüğünde, araştırmanın denendiği deney grubunun süreç açısından daha başarılı olduğu söylenebilir. Öğrencilerin derse olan aktif katılımları, öğretmen ve öğrencilerin kendi aralarındaki iletişim, öğrencilerin çalışmaya karşı istekli olmaları, işbirliği içinde çalışmaları bu sürece birer örnek olabilir.

Bu noktada söylenmesi gereken bir husus ise araştırma süresince yaşanan uygulama zorluklarıdır. Uygulamaya dönük zorlukların varlığı yadsınamayacak bir durumdur. Öğrencilerin geleneksel olarak alışmış oldukları şekilde her uygulamayı sınav endeksli düşünmesi, sınavda çıkmayan derslere karşı olumsuz tutum sergilemeleri, öğrencilerin ve velilerin ders sürecini bir rekabet ortamına dönüştürmesi, velilerin öğrenciler üzerinde sınavda ağırlıklı çıkan derslere çalışmaları konusunda baskı yapmaları gibi nedenler uygulamada bazı zorlukları da beraberinde getirmektedir.

Bunun yanında teknik ve teknolojik imkânların kısıtllı̆ı̆ı ve sınav sistemimizin öğrencileri yarış ve rekabet ortamına zorlaması gibi faktörler de uygulama zorlukları arasında sayılabilir.

Yaklaşımının İlköğretim Din Kültürü ve Ahlak Bilgisi Dersinin Amaçlarının Gerçekleşmesine Etkisi,Ankara Üniversitesi SBE, (Yayınlanmamış Doktora Tezi), Ankara, 2008. 
Uygulama zorluklarının belki de en önemlisi, öğrencilerin benimsemiş oldukları hazır bilgiyi ezberlemeye yönelik öğrenme kültürleridir. ${ }^{26}$ Öğrenciler, alışmış oldukları eğitim sisteminde hazır ve ezber bilgiye ulaştıklarından, kendilerinin öğrenmenin içerisinde yer aldıkları, sorumluluğun kendilerinde olduğu, yaparak öğrenecekleri bir eğitim ortamına direnç göstermektedirler.

Yaşanan bir diğer sorun geleneksel anlayışla işlenen derslerde süre yeterli iken yapılandırmacı yaklaşımda öğrenci etkinliği, öğretmen rehberliği ön planda olduğundan bu sürenin yeterli olamaması da sayılabilir. Çünkü ders içi etkinlikler geleneksel yaklaşımlardan daha çok zaman almaktadır. Aynı şekilde öğrenci etkinliğine dayalı bu yaklaşım çerçevesinde işlenen derste öğrenciler arasında gürültü çok fazla olmakta, bu sorunu engellemek için de sinıf mevcutlarının azaltılması gerekmektedir.

Ayrıca din kültürü ve ahlak bilgisi dersleri, adından da anlaşılacağı üzere ahlak ağırlıklı dersler olduğundan dolayı, öğrenciler, bu niteliklere hazır ve aşina olmaktadırlar. Dolayısıyla, her iki grupta da amaçların gerçekleşme düzeyleri yüksek ve çok da farklı değildir. ${ }^{27}$

Netice itibariyle, uygulamada bazı zorluklar ve aksaklıklar olmasına rağmen, araştırmamızda da ulaşılan neticelerden birisi, yapılandırmacılık yaklaşımı çerçevesinde öğrenme-öğretme uygulamaları öğrencinin aktif katılımını, işbirliği içinde çalışmalarını, kendilerine olan güveni arttırdığını, kendi bilgilerini kendilerinin yapılandırdıklarını sağlamaktadır. Bir diğeri, ulaşılan amaçların gerçekleşme düzeyi yüksek olmakla birlikte geleneksel yaklaşımdan çok fazla farklılaşmamaktadır. Bu bağlamda, araştırmanın denencelerini değerlendirecek olursak; araştırmanın birinci denencesi; Araştırmaya katılan öğrencilerin, öntest puanlart, deney ve kontrol gruplarına göre anlamlı bir farklllık göstermektedir şeklinde ifade edilmiştir. Bu hipotezi test etmek amacıyla, araştırmaya katılan kontrol ve deney gruplar arasında, uygulanan başarı testi neticesinde ilişkisiz örneklemler t-testi yapılmış ve buna göre kontrol ve deney grupları arasında anlamlı bir farklılık olup olmadığı test edilmiştir.

Buna göre, 6. sınıflar için ön test puan ortalamaları, kontrol grubu için 13.76 iken, deney grubu için 14.44 olarak tespit edilmiştir. Bu puanlara göre anlaml1lık değeri.516 çıkmıştır. İstatistikî anlamda bu rakam anlamlı bir farklılık teşkil etmemektedir. Dolayısıyla araştırmaya katılan 6 . sınıf kontrol ve deney grupları arasında istatistikî anlamda anlamlı bir farkllılı yoktur denebilir.

26 Uygulama zorlukları konusunda geniş bilgi için Bkz. Özcan Erkan Akgün, "Uygulayanların Deneyim ve Görüşleriyle Yapıcı Yaklaşım ve Yapıcı Yaklaşımların Uygulanması Öncesinde Yapılması Önerilen Davranışlar," Yüzüncüyıl Elektronik Eğitim Fakültesi Dergisi, C.II, S.II, s. 10.

27 Bkz. Akgün, "Uygulayanların Deneyim ve Görüşleriyle Yapıcı Yaklaşım ve Yapıcı Yaklaşımların Uygulanması Öncesinde Yapılması Önerilen Davranışlar," s. 10-15. 
Aynı testi 7. sınıflarda uyguladığımızda karşımıza çıkan tablo şu şekilde olmaktadır: Kontrol grubu için öntest puanları 16.29 iken, deney grubu için 16.19 olarak tespit edilmiştir. Anlamlılık değeri ise.902'dir. Buna göre, 7. sınıf kontrol ve deney grubu arasında istatistikî anlamda anlamlı bir farklılık yoktur denilebilir.

Bu durum 8. sınıflarda ise şu şekilde gözlenmiştir: kontrol grubu için ön test puan ortalaması 15.50 iken, deney grubu için bu puan 14.00 olarak tespit edilmiştir. Anlamlılık değeri ise .094 olarak bulunmuştur. Buna göre, 8. sınıf kontrol ve deney grupları arasında öntest ortalama puanları açısından anlamlı bir farklılık olmadı̆̆ 1 söylenebilir.

Araştırmada iki grubun karşılaştırılması yapıldığında ön koşul olarak gruplar arası denkliğin sağlanması gerektiği düşünülürse bu durum araştırmanın ön koşulunun gerçekleştiğini ve araştırmanın başında sınıflar arası kontrol ve deney gruplarının başarı düzeylerinin eşit olduğunu göstermektedir.

Araştırmanın ikinci denencesi; İlköğretim Din Kültürü ve Ahlak Bilgisi Dersinde belirlenen ünitelerde yapılandırmacılık yaklaşımına uygun olarak hazırlanan etkinliklerle desteklenerek gerçekleştirilen öğretimin uygulandığı grup (deney grubu) ile geleneksel yaklaşımlara göre ö̆̆retimin uygulandığı grup (kontrol grubu), öğrenme düzeyleri açısından (sontest puanları baklmindan) bir farklılık göstermektedir şeklinde ifade edilmektedir.

Bu hipotez 6. sınıflar açısından değerlendirildiğinde kontrol grubu için sontest puanı 17.42 iken deney grubu için bu sonuç 16.88, anlamlılık değeri ise .551 olarak tespit edilmiştir. Buna göre 6. sınıflar için, kontrol ve deney grubu arasında sontestleri bakımından istatistikî olarak anlamlı bir farklılık mevcut değildir denebilir.

7. sınıf için incelendiğinde ise; kontrol grubunun sontest puanı 16.70 iken, deney grubunun sontest puanı 17.84, anlamlılık değeri ise .175 olarak tespit edilmiştir. Buna göre, 7. sınıflar için kontrol ve deney grupları için sontest puanları arasında istatistikî açıdan anlamlı bir farklılık mevcut değildir denebilir.

8. sınıf açısında ise durum şu şekildedir: 8. sınıf kontrol grubu sontest puanı 16.66 iken deney grubu için bu puan 17.13, anlamlılık değeri ise .506 olarak tespit edilmiştir. Buna göre, 8. sinıflar için kontrol ve deney grupları için sontest puanları arasında istatistikî açıdan anlamlı bir farklılık mevcut değildir denebilir.

Her üç sınıfta da istatistikî anlamda bir farklılık çıkmamasının nedeni, yapılandırmacılık yaklaşımına uygun olarak gerçekleştirilen gerek sınıf içi gerekse sınıf dışı etkinliklerin öğrencilerin alışık olmadığı bir sistem olması ve öğrencilerin çoktan seçmeli testlerde alışkanlık olduğu üzere daha başarılı olmaları gösterilebilir. 
Araştırmanın 3. denencesi; deney ve kontrol gruplarının dersteki kalıcılık testi sonuçları arasında anlamlı bir farklılık vardır şeklinde ifade edilmiştir.

6. sınıf için kalıcılık testi sonuçları şu şekildedir: Kontrol grubu kalıcılık puanı 16.47, deney grubunun 17.50, anlamlılık değeri ise .205 'tir. Buna göre, gruplar arasında kalıcılık puanları arasındaki matematiksel fark istatistikî anlamda bir farklılık olarak kabul edilmemektedir. Her içi grup arasında anlamlı bir farklılık mevcut değildir denebilir.

7. sınıf için kalıcılık testi sonuçları kontrol grubu puanı 18.14 iken deney grubunun kalıcılık puanı 17.73, anlamlılık değeri ise .500 olarak tespit edilmiştir. Buna göre 7. sınıf kontrol ve deney grubu arasından istatistikî açıdan anlamlı bir farklılık mevcut değildir.

8. sınıf kalıcılık testi sonuçları ise şu şekildedir: kontrol grubu kalıcılık puanı 19.95 iken, deney grubu kalıcılık puanı 17.50, anlamlılık değeri ise .000'dır. Buna göre, 8. sınıf kontrol ve deney grupları arasında kalıcılık puanları arasında istatistikî açıdan anlamlı bir farklılık mevcuttur denebilir.

Üç grup arasında bir değerlendirme yapılacak olursa, 6 ve 7. sınıflar arasında anlamlı bir farklılık mevcut değilken 8. sınıfta böyle bir kontrol grubu lehine böyle bir farkın çıkması geleneksel eğitime alışkın sınıflarda 8. sınıf OKS sınavına yönelik çalışmanın onlara sağladığı avantajla açıklanabilir.

Araştırmanın 4. denencesi, Araştırmaya katılan kontrol grubundaki öğrencilerin sontest puanları, cinsiyetlerine, ögrencilerin şimdiye kadar yaşadığı yer durumuna, ailenin ekonomik durumuna, annenin öğrenim durumuna, babanın öğrenim durumuna, annenin mesleğine, babanın mesleğine ve çalışma ortamlarına göre farklılaşmaktadır şeklinde ifade edilmektedir.

6. sınıf kontrol grubu için deneklerin babalarının eğitimine göre 7. sınıf için ise annelerinin eğitimine göre anlamlı bir şekilde farklılaşmaktadır.

8. sınıf kontrol grubunun sontest ortalama puanları, Öğrencilerin cinsiyetlerine göre, çalışma ortamlarına göre ve babalarının eğitimlerine göre anlamlı bir şekilde farklılık göstermektedir.

Araştırmanın 5. denencesi, deney grubundaki ögrencilerin sontest ortalama puanları, aynı bă̆ımsı değişkenlere göre farklılaşmaktadır şeklinde ifade edilmiştir.

8. sınıf deney grubu sontest puanları, Eğitim desteği alıp almamalarına göre ise anlamlı bir şekilde farklılaşmaktadır.

Araştırmanın 6. denencesi, kontrol grubundaki öğrencilerin kalıcılık puanları, bağımsız değişkenlere göre farklılaşmaktadır şeklinde ifade edilmiştir.

6. sınıf kontrol grubundaki öğrencilerin kalıcılık puanları, gelir durumlarına göre ve kardeş sayılarına göre; 7. sınıf kontrol grubundaki öğrencilerin 
çalışma ortamlarına göre, 8. sınıf kontrol grubundaki öğrencilerin ise babalarının mesleğine göre anlamlı bir şekilde farklılaşmaktadır.

Araştırmanın 7. denencesi, deney grubundaki öğrencilerin kalıcılık puanları, bağımsı değişkenlere göre farklılaşmaktadır şeklinde ifade edilmiştir.

Bu denenceye göre, 6. sınıf deney grubundaki öğrencilerin kalıcılık puanları, çalışma ortamlarına göre ve babalarının eğitimlerine göre; 8. sınıf deney grubundaki öğrencilerin kalıcılık puanları ise eğitim desteği alıp almamalarına göre anlamlı bir şekilde farklılık göstermektedir. 